\title{
The Modification of the Perforated Plate in the Fluidized-Bed Combustor to Analyze Heat Convection Rate and Temperature
}

\author{
Erdiwansyah (D), ${ }^{1,2}$ Mahidin (D), ${ }^{3}$ Husni Husin, ${ }^{3}$ Muhammad Faisal, ${ }^{4}$ Muhtadin, ${ }^{4}$ Asri Gani, ${ }^{3}$ \\ R. E Sardjono, ${ }^{5}$ and Rizalman Mamat $^{6}$ \\ ${ }^{1}$ Doctoral Program, School of Engineering, Post Graduate Program, Universitas Syiah Kuala, Banda Aceh 23111, Indonesia \\ ${ }^{2}$ Faculty of Engineering, Universitas Serambi Mekkah, Banda Aceh 23245, Indonesia \\ ${ }^{3}$ Department of Chemical Engineering, Universitas Syiah Kuala, Banda Aceh 23111, Indonesia \\ ${ }^{4}$ Department of Mechanical Engineering, Universitas Abulyatama Aceh, Aceh Besar 23372, Indonesia \\ ${ }^{5}$ Department of Chemistry, Faculty of Mathematics and Science, Universitas Pendidikan Indonesia, Bandung 40522, Indonesia \\ ${ }^{6}$ Faculty of Mechanical Engineering, Universiti Malaysia Pahang, Gambang 26600, Malaysia
}

Correspondence should be addressed to Erdiwansyah; erdi.wansyah@yahoo.co.id and Mahidin; mahidin@unsyiah.ac.id

Received 7 August 2021; Revised 6 October 2021; Accepted 25 October 2021; Published 25 November 2021

Academic Editor: Ashwani K. Gupta

Copyright (c) 2021 Erdiwansyah et al. This is an open access article distributed under the Creative Commons Attribution License, which permits unrestricted use, distribution, and reproduction in any medium, provided the original work is properly cited.

\begin{abstract}
Investigation of combustion temperature through experiments with a wide range of fuels, both solid and liquid, is continuously being conducted by scientists around the world, while the measurement of heat transfer rate can be analyzed when the combustion process occurs. Previous research has generally been conducted using liquefied gas, fossil fuels, and alcohol additives. Specifically, the research in this work investigated the convection heat rate and combustion temperature through the modification of the perforated plate. The experiment was conducted in the fluidized-bed combustor (FBC) fuel chamber using solid waste fuel of oil palm biomass. Measurements were performed at four different points using the HotTemp HT-306 Digital Thermometer. The results of the experiment showed that the convection heat rate in measurement one (M-I) reached $8.258 \mathrm{~W} / \mathrm{m}^{2}$ for palm kernel shell (PKS) fuel. Meanwhile, in measurement two (M-II), the convection rate of $7.392 \mathrm{~W} / \mathrm{m}^{2}$ was produced by oil palm midrib $(\mathrm{OPM})$ fuel. The highest combustion temperature was recorded with OPM fuel $\left(884^{\circ} \mathrm{C}\right)$ at M-I. However, the combustion temperature of the PKS combustion process is higher at $896^{\circ} \mathrm{C}$ but shows a less good trend than OPM. Overall, the measurement results of the three types of fuel used to modify the perforated plate applied in the FBC fuel chamber are excellent. It can be proven that the fuel is put into the combustion chamber with nothing left.
\end{abstract}

\section{Introduction}

Combustion research continues to this day using both solid and liquid fuels. Experiments with combustion were conducted to determine the temperature level of the fuel used. In general, combustion temperature analysis is performed on motor vehicle engines, for example, [1-5]. Temperature analysis of combustion engines uses many fossil fuels, diesel, petroleum, and mixed fuels or additives [6-8], while the analysis of combustion temperature using solid fuels such as palm oil biomass is still very rare in various publications. Palm oil biomass is a source of renewable energy that can be used as a substitute for fossil fuels that are depleted over time.
Perforated plates play a very effective role in the resistance of fire collected from the fuel provided [9]. The resistance of the perforated plate to the flame is the same as the metal mesh as described in the studies [10-12]. The main function of the perforated plate was to provide the speed of the flame as described in the study [13-15]. Modified perforated plates can significantly lower the speed of flame downstream as discussed in [16-19]. Perforated plates have the potential to extinguish flames.

In recent years, investigations into combustion temperatures using solid wastes such as palm oil biomass have begun to be in demand by some researchers. However, the use of palm oil biomass as fuel to analyze combustion temperatures in the FBC fuel chamber is still very minimal 
and difficult to find in various publications. Palm oil biomass is a renewable energy source that can be used for heating, cooling, and electrical energy. The availability of renewable energy sources in Southeast Asia is also very adequate [20-22]. The availability of renewable energy sources, especially in Indonesia today, is very abundant, especially solid waste biomass, which can be used as a power plant [23-27]. However, abundant energy sources cannot be utilized to the maximum.

Research on the interaction of flames with the application of perforated plates has been discussed in several pieces of kinds of literature, while the transition to flame acceleration and quenching has also been recently investigated [14]. Investigations into combustion temperatures have also been widely presented in various literature studies. In general, investigations into combustion temperature and heat transfer are generally conducted using fossil fuels and a mixture of alcohol and fuel additives. However, investigations of combustion temperature and heat transfer in FBC chambers using solid waste biomass are still very rare in the literature. Therefore, to know the conditions of combustion temperature and heat transfer in the combustion chamber, FBC conducted a series of experiments by modifying the perforated plate. Palm oil biomass solid waste fuel is used to investigate combustion temperature levels and heat transfer by providing sufficient air through a perforated plate.

\section{Experiment Setup and Materials}

Experiments conducted in this study were analyses of the level of combustion temperature in the fluidized-bed combustor (FBC) chamber by making modifications to the perforated plates. Combustion testing uses solid waste biomass fuel from renewable energy sources such as palm kernel shell (PKS), oil palm midrib (OPM), and empty fruit bunches (EFB). The design of the FBC burn chamber used in this work is as short as shown in Figure 1. As for the analysis of temperature data in the $\mathrm{FBC}$ room, a digital thermometer brand HotTemp HT-306 is used. This digital thermometer can analyze the maximum temperature up to $1300^{\circ} \mathrm{C}$ as shown in Figure 2, while the modified perforated plate has a circle shape with a hole and two clasps on the edge and one main direction right in the middle of the plate which is shown in Figure 3. The function of the perforated plate is to supply air into the FBC chamber so that the fuel is inserted unsaturated due to the presence of incoming air to stir the fuel.

Furthermore, the steaming of combustion temperature in this study uses digital thermometer HT-306 as shown in Figure 3, while the specifications of digital thermometer HT306 are presented in Table 1.

Research to analyze convection heat rate in FBC fuel chambers through the modification of perforated plates using palm oil biomass solid waste fuels such as palm kernel shell (PKS), oil palm midrib (OPM), and empty fruit bunches (EFB) is shown in Figure 4. Each fuel used weighs

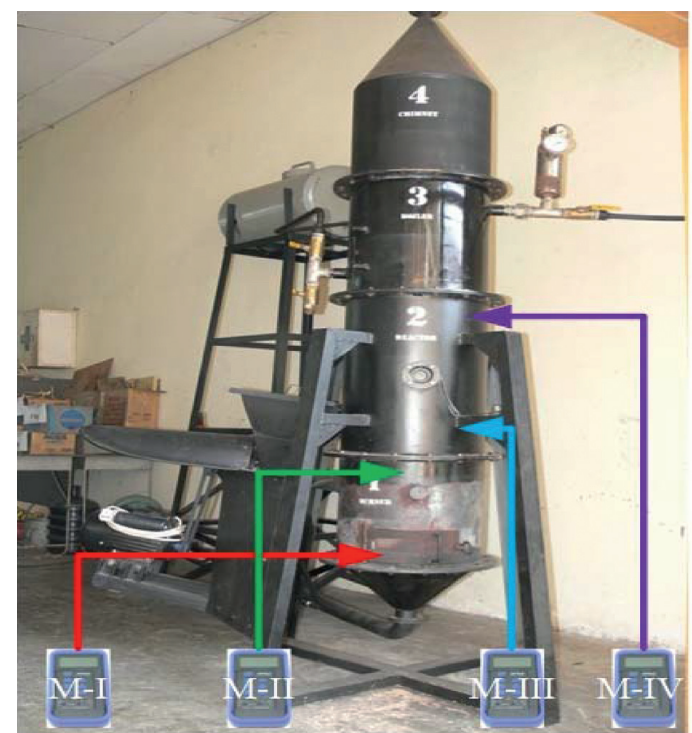

FIGURE 1: Schematic diagram of the combustion chamber (FBC).

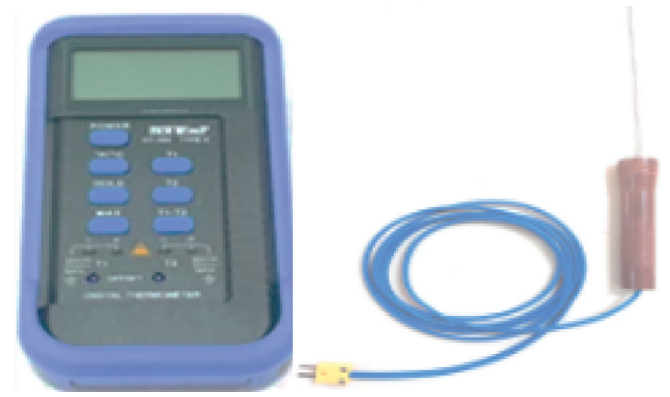

FIgURE 2: Digital thermometer merk HotTemp HT-306.

the same as $2.5 \mathrm{~kg}$. Data collection of convection heat rate and combustion temperature taken at four different points is shown in Figure 1 [28]. The use of palm oil biomass for conversion into bioenergy has been investigated in several previous studies [29-31]. The investigations carried out in their research overall convert biomass into environmentally friendly bioenergy, while in the tests carried out in this study, the modification of the hollow plate aims to investigate the temperature level and the rate of heat convection so that it can produce energy. However, this test has not yet reached the calculation of the energy produced, but to calculate the energy output from this combustion is the next work.

The palm oil biomass solid waste material used in this work was collected from a palm oil mill in Aceh Province. Oil palm biomass such as EFB and OPM is collected in the crude form. Meanwhile, PKS biomass is directly collected at the factory after going through crushing and then dried before being used as a fuel. As for the EFB and OPM, they must be cut first and then dried. The process of making biomass for fuel in this study is as presented in Figure 5.

Analysis for the calculation of convection heat rates was applied in the study using the following equation $[32,33]$ : 

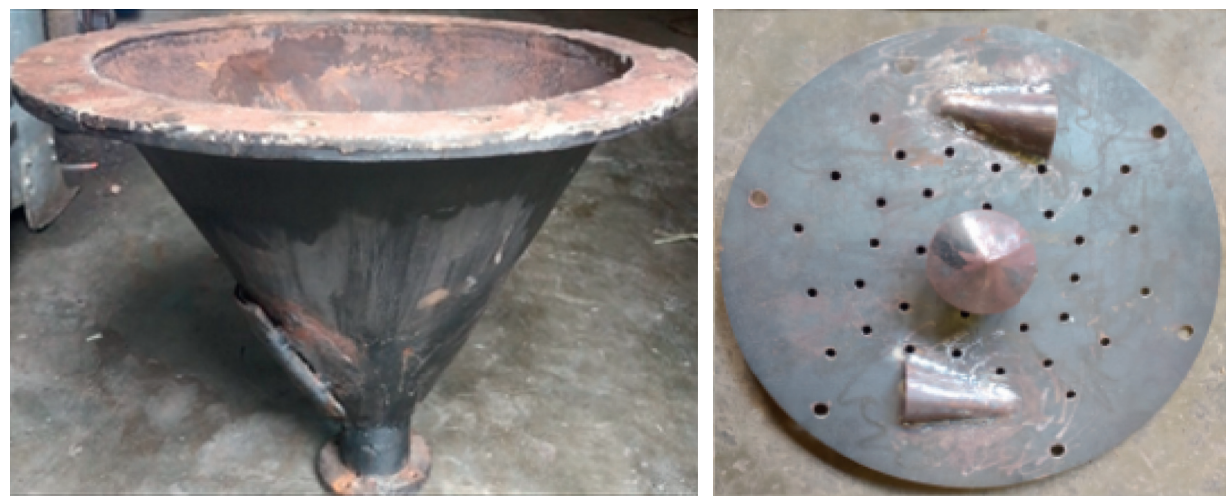

Figure 3: Modification of the perforated plate.

TABLE 1: Specifications of digital thermometer HT-306.

\begin{tabular}{lc}
\hline Component & Measurement \\
\hline Power supply & Battery $6 \mathrm{~F} 229 \mathrm{~V}$ \\
Response time & 15 seconds \\
Wide measuring range & $-50^{\circ} \mathrm{C}-+1300^{\circ} \mathrm{C}\left(-58^{\circ} \mathrm{F}-+1999^{\circ} \mathrm{F}\right)$ \\
Input sensor & Thermocouple type "K" \\
Resolution & $\mathrm{HT}-306: 1^{\circ} \mathrm{C} / 1^{\circ} \mathrm{F}$ \\
Model HT-306 & Dual-channel input \\
\hline
\end{tabular}

$$
q=\frac{T 1-T 5}{1 / h o A o+(\ln (r o 1 / r i 1) / k 1)+(\ln (r o 2 / r i 2) / k 2)+(\ln (r o 3 / r i 3) / k 1)+1 / h i A i},
$$

where $T 1$ is the temperature flame, $T 5$ is the temperature outer wall, rol is the outer radius of the combustor, ril is the mine radius of the combustor, ro2 is the outer radius of insulation, ri2 is the inner radius of insulation, ri3 is the radius of the cylinder, $k 1$ is the thermal conductivity of the plate, $k 2$ is the thermal conductivity of the insulation, ho is the coefficient convection heat transfer from outer wall to air, $h i$ is the coefficient in the wall from the combustor chamber to the inner wall, $A o$ is the outer cross-sectional area, and $A i$ is the inner cross-sectional area.

\section{Results and Discussion}

The research in this work is specifically to analyze the convection heat rate and combustion temperature level of the FBC indoor combustion process using palm biomass fuel (PKS, OPM, and EFB). The FBC combustion chamber is modified by a two-way hole and the main hole and steering wheel in the middle of the plate which are shown in Figure 3. This perforated plate is modified to provide air supply into the FBC fuel chamber so that the fuel incorporated can burn as a whole. Measurements of convection heat rate and combustion temperature are analyzed at four predetermined points as shown in Figure 1. The goal of the end-of-analysis results at each step is to assess the level of combustion efficiency in the FBC combustion chamber with perforated plate modification.

Based on the results of measurements conducted with a digital thermometer, brand HotTemp HT-306 shows that the convection heat rate in $\mathrm{M}-\mathrm{I}$ reached $8258 \mathrm{~W} / \mathrm{m}^{2}$ recorded for $\mathrm{PKS}$ fuel, while the convection heat rate obtained from OPM and EFB fuels reached $7493 \mathrm{~W} / \mathrm{m}^{2}$ and $6268 \mathrm{~W} / \mathrm{m}^{2}$, respectively, as shown in Figure 4 . The high heat convection rate produced by PKS fuel is due to the longer combustion time compared to OPM and EFB. The results of the combustion temperature analysis of the three fuels used showed varying results, where the trend of combustion temperature for OPM fuel shows the best of PKS and OPM. The combustion temperature analyzed for PKS fuel is $948^{\circ} \mathrm{C}$ which is higher than that of OPM and EFB, respectively $\left(884^{\circ} \mathrm{C}\right.$ and $\left.776^{\circ} \mathrm{C}\right)$, as shown in Figure 6 . Tests performed with EFB fuel and temperatures were shown to be more lopsided at the time until the end of combustion. This indicates that the modification of the perforated plate can work well. The modification of the perforated plate can supply enough air so that the fuel is thoroughly inserted and nothing is left as shown in Figure 7.

Figure 8 Analysis of convection heat rate and combustion temperature measured on M-II showed that OPM fuel was higher than PKS and EFB. When compared to the convection heat rate on M-I, it showed a difference. This is because the measurement on M-II is the end of fire so that when OPM has burned, fire immediately spouts upwards, while fire burning at PKS and EFB is a little more ramped. The convection heat rate recorded with OPM fuel reaches $7.392 \mathrm{~W} / \mathrm{m}^{2}$ compared to $7.232 \mathrm{~W} / \mathrm{m}^{2}$ for the PKS and $7.203 \mathrm{~W} / \mathrm{m}^{2}$ for the EFB as shown in Figure 9. 


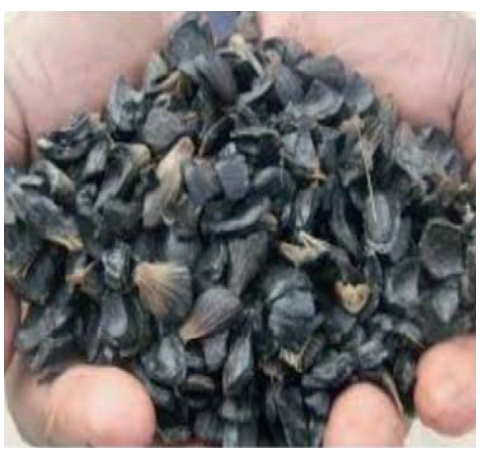

PKS

(a)

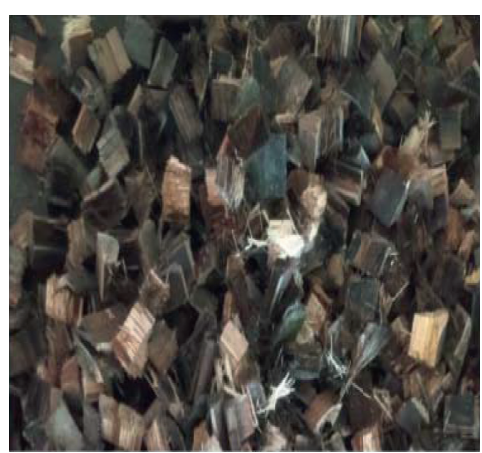

OPM

(b)

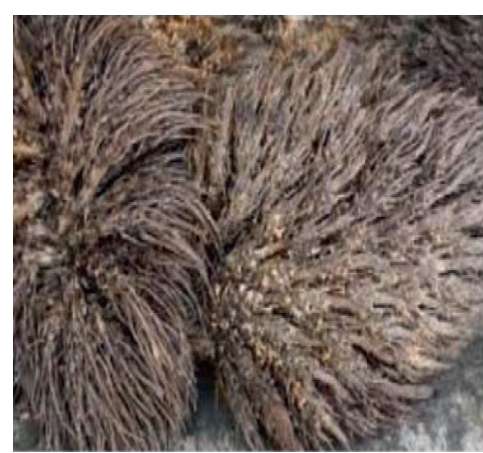

EFB

(c)

Figure 4: Types of solid waste biomass, palm oil. (a) PKS. (b) OPM. (c) EFB.

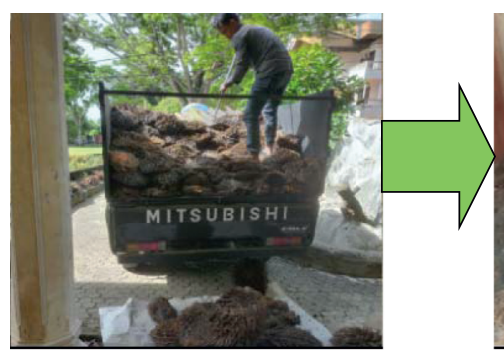

Fresh Fruit Bunches

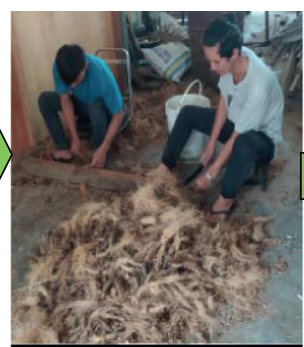

Cutting Process

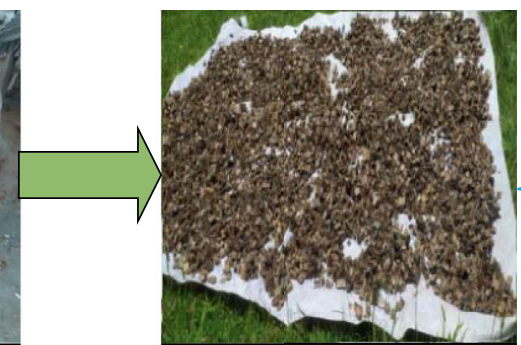

Drying Process

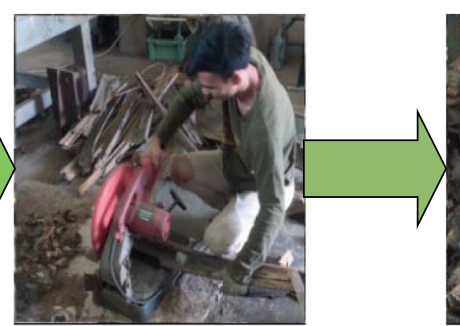

Cutting Process

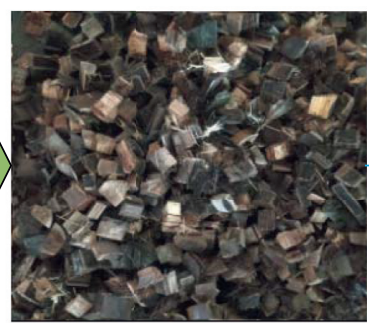

Result of biomass production
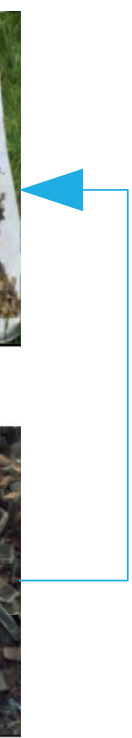

Figure 5: Production process of biomass.

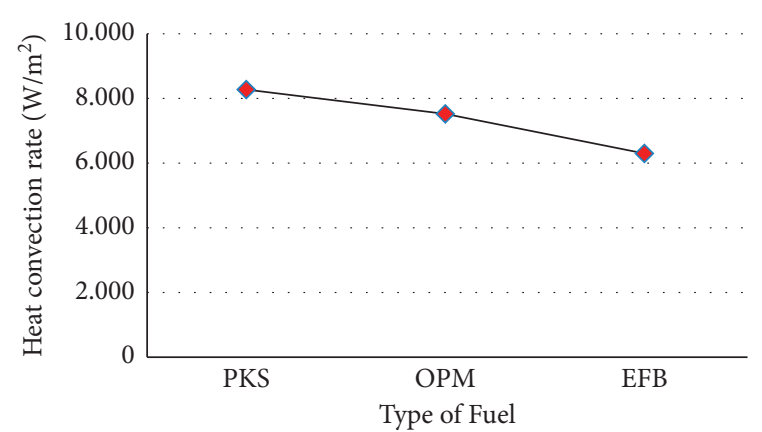

Figure 6: Heat convection rate for different fuels at the measurements (M-I).

The combustion process with PKS fuel shows a higher temperature trend but is not optimal compared to OPM and $\mathrm{EFB}$, while the combustion temperature trend for OPM and EFB burning materials shows an excellent trend. The maximum temperature from the test for each OPM, PKS, and EFB fuel at the M-II measurement point is $874^{\circ} \mathrm{C}, 840^{\circ} \mathrm{C}$, and $860^{\circ} \mathrm{C}$ and is shown in Figure 10. The combustion

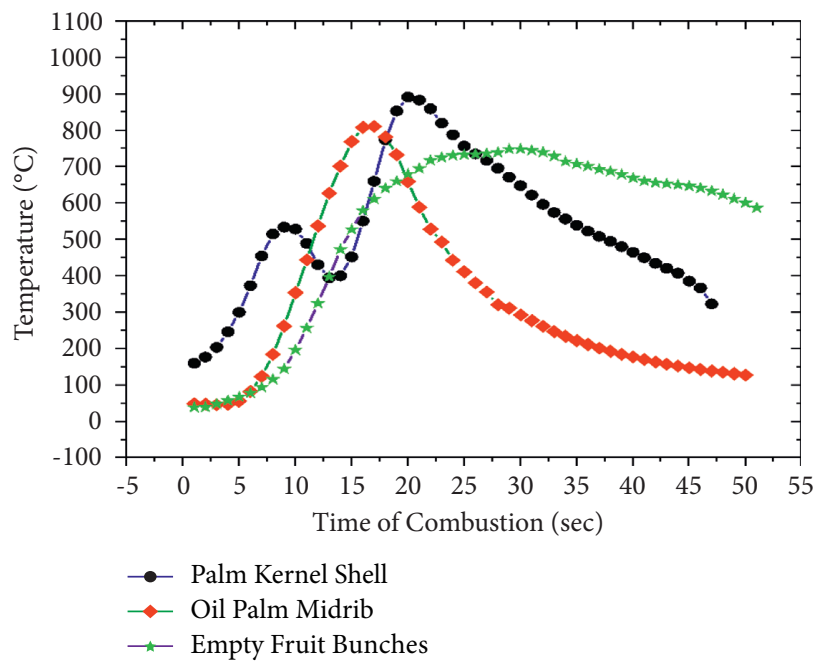

Figure 7: Profile temperatures for different fuels at the measurements (M-I). 


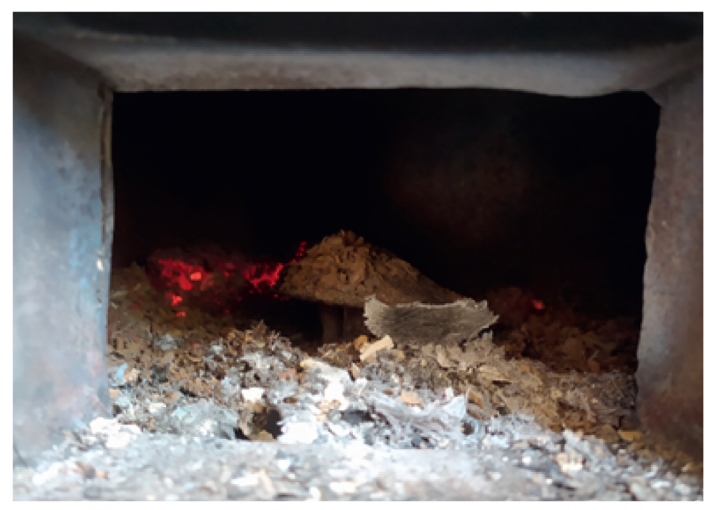

FIgURE 8: Residual ashes' burning.

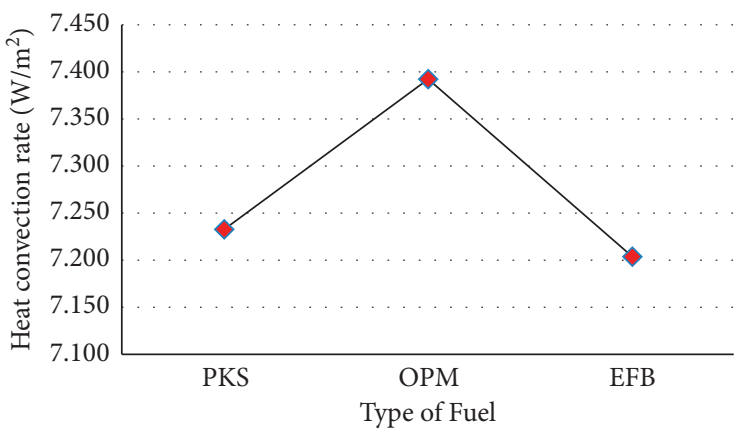

FIgURE 9: Heat convection rate for different fuels at the measurements (M-II).

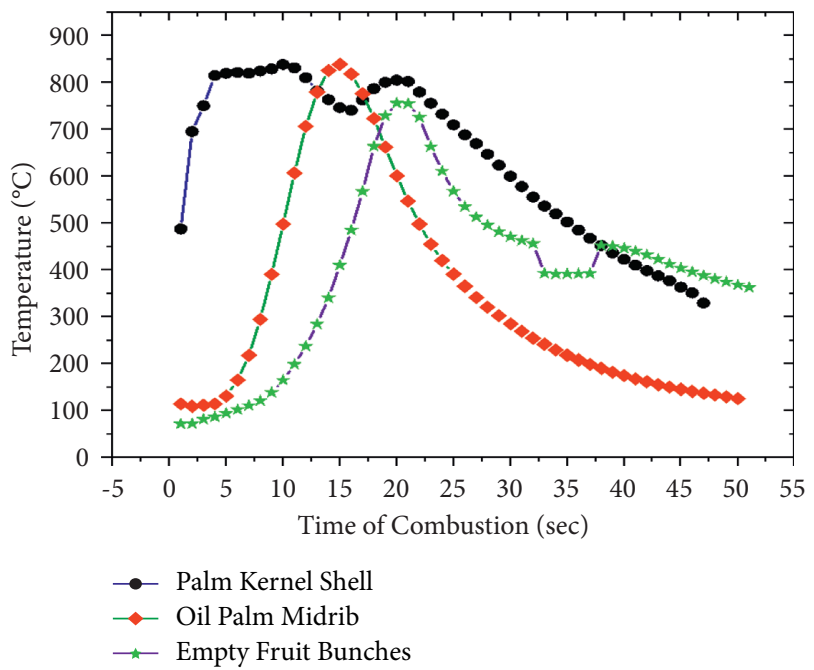

Figure 10: Profile temperature for different fuels at the measurement (M-II).

temperature levels recorded in this study are higher than in previous studies [28, 34].

Furthermore, analysis and measurements were performed on measurement three (M-III) for convection heat rates for different fuels and combustion times. The convection heat rate measured in M-III shows that PKS fuel is $8.493 \mathrm{~W} / \mathrm{m}^{2}$ higher than OPM and EFB at $6.274 \mathrm{~W} / \mathrm{m}^{2}$ and $5.912 \mathrm{~W} / \mathrm{m}^{2}$, respectively, as shown in Figure 11. This

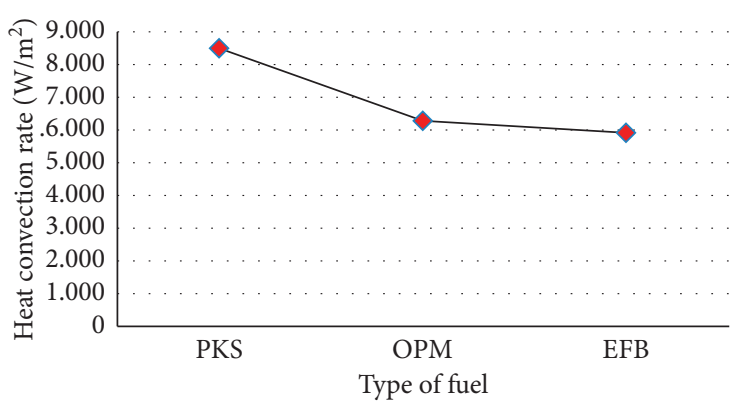

Figure 11: Heat convection rate for different fuels at the measurements (M-III).

measurement is done on a freeboard that is above the combustor or in the room before reaching the boiler.

The results of the combustion temperature measurement on the M-III OPM fuel show an excellent trend. The maximum combustion temperature of the OPM combustion process reaches $764^{\circ} \mathrm{C}$, slightly lower than the PKS $\left(971^{\circ} \mathrm{C}\right)$. However, the temperature trend displayed by the PKS is not optimal because the combustion fire of the PKS is uneven so that the temperature displays up and down as shown in Figure 12.

The latest analysis in this work for the measurement of convection heat rate and combustion temperature was performed on a chimney (M-IV). Measurements at this point are important to monitor the level of combustion temperature and convection heat rate before reaching the boiler so that the boiler heating and released steam can be known. If the combustion temperature gets higher, then the steam that can be converted into energy gets bigger. The results showed that PKS fuel showed a higher convection heat rate than OPM and EFB. The convection heat rates of the three fuels used reached $5.728 \mathrm{~W} / \mathrm{m}^{2}, 5.695 \mathrm{~W} / \mathrm{m}^{2}$, and $5.394 \mathrm{~W} / \mathrm{m}^{2}$, respectively, as shown in Figure 13. However, the convection heat rate in M-IV measurement was significantly lower than that of M-I, M-II, and M-III, while the combustion temperature in M-IV decreased significantly from M-I, M-II, and M-III for all tests performed. The highest temperatures reached $699^{\circ} \mathrm{C}$ for $\mathrm{PKS}, 707^{\circ} \mathrm{C}$ for $\mathrm{OPM}$, and $690^{\circ} \mathrm{C}$ for $\mathrm{EFB}$ as shown in Figure 14. The combustion temperature trend of OPM and EFB fuels is better than that of PKS. The trend of combustion temperature for PKS fuel is unstable because the air entering the FBC fuel chamber is not enough. This is because the modified air hole is covered by fuel so that the air does not enter optimally. The overall analysis for convection heat rate in this study shows that it is higher than the research conducted by Liu et al. [35], where the research is conducted for analysis in utilizing geothermal energy efficiently. In addition, the results of the analysis conducted in their study showed that the combustion temperature was lower than in this study.

Based on the results of the overall analysis, the convection heat rate for PKS fuel is higher than OPM and EFB, while the combustion temperature of the PKS fuel experiment is higher than that of OPM and EFB. Modification of the perforated plate shows a fairly perfect result. The successful modification 


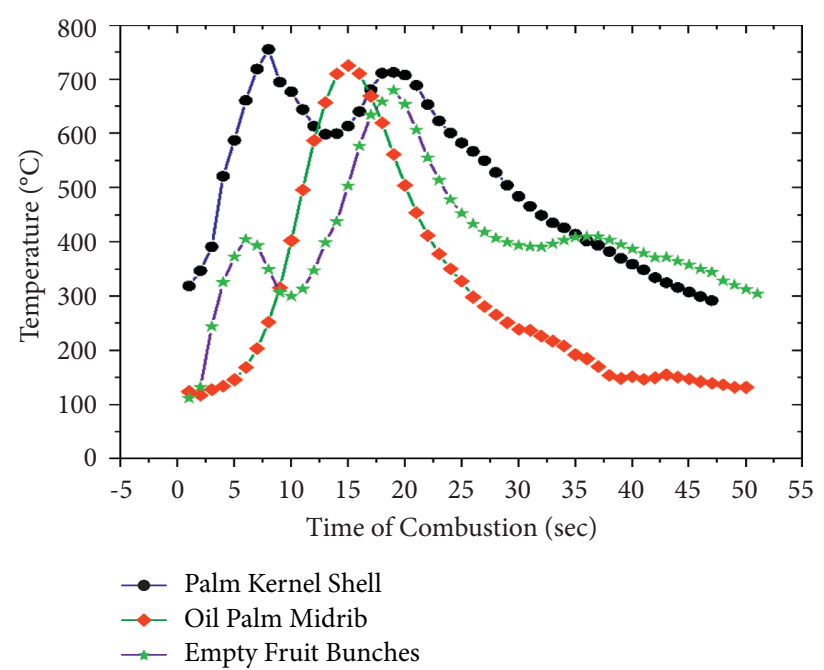

Figure 12: Profile temperature for different fuels at the measurement (M-III).

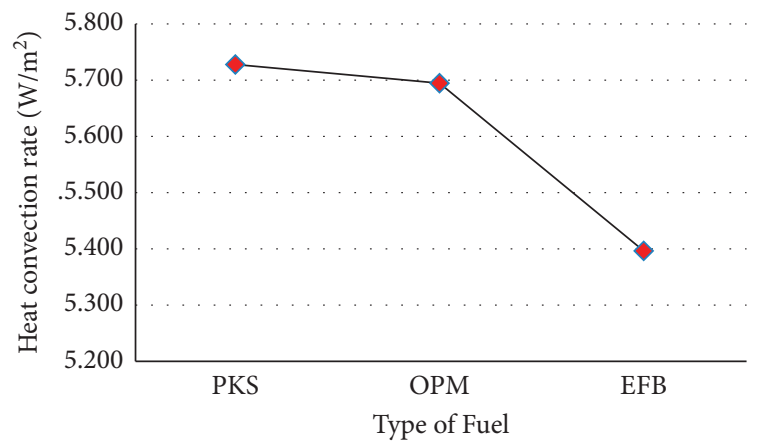

Figure 13: Heat convection rate for different fuels at the measurements (M-IV).

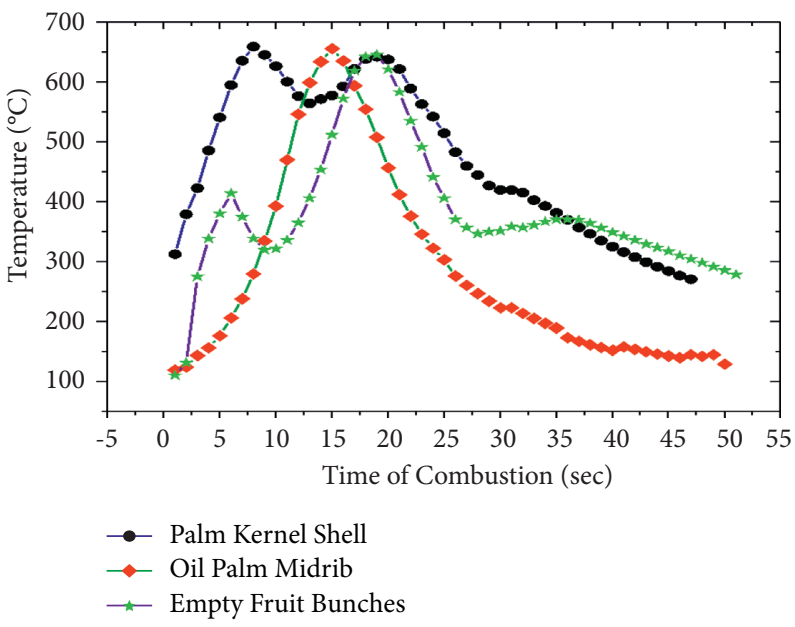

Figure 14: Profile temperature for different fuels at the measurement (M-IV).

of this perforated plate as the combustion fire is shown in Figure 15 where it can be seen that the rest of the ash is burning from the tests conducted. Modification of the perforated plate can run very well to supply air in the combustion chamber.

The modification of the hollow plate carried out in this work is specifically to analyze the heat convection rate and combustion temperature. Measurements were made at four different points of each fuel used. Based on the overall test results, the modifications applied in the study showed that they were more optimal than those without modifications. An in-depth investigation of the efficiency of the furnace will be carried out in future work. In addition, the 


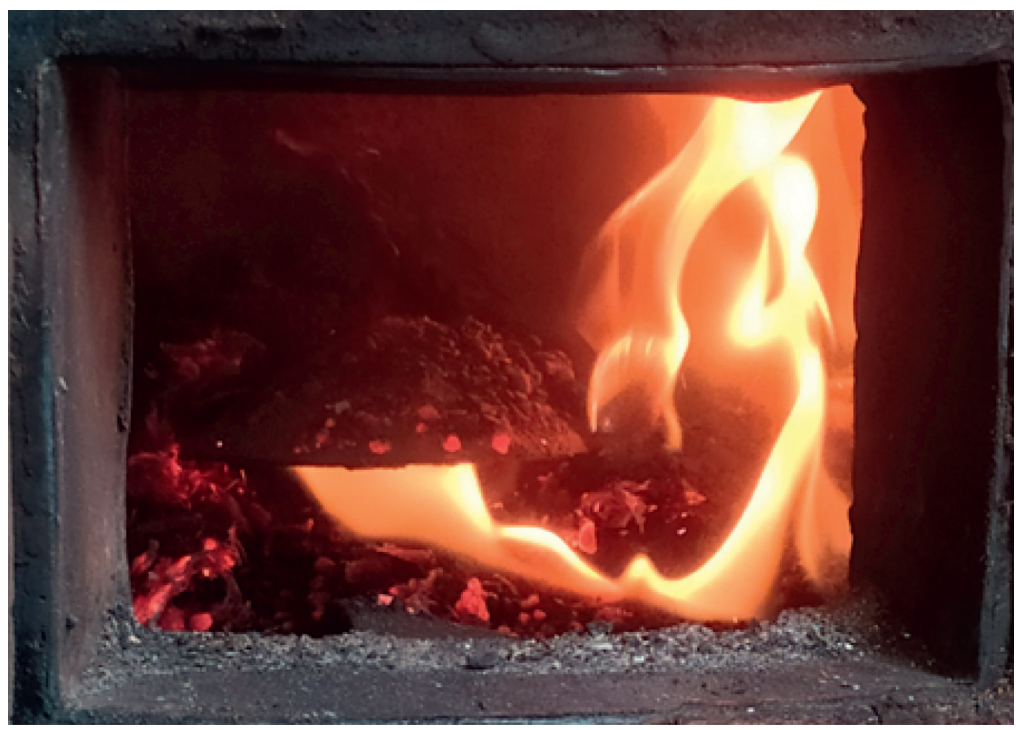

Figure 15: Display of combustion fire in the combustion chamber.

investigation of the combustion efficiency of different plate modifications will also be a priority for the next work.

\section{Conclusion}

The tests conducted in this work are specifically to analyze the convection heat rates and combustion temperatures in FBC fuels with oil palm biomass fuels such as PKS, OPM, and EFB. Measurements are performed at four different points, and for each point, the heat convection rate and the resulting temperature are calculated. Based on the results of the experiments conducted, this can be concluded as follows:

(1) The convection heat rate calculated on M-I reached $8.258 \mathrm{~W} / \mathrm{m}^{2}$ recorded on PKS fuel. As for the measurement on $\mathrm{M}-\mathrm{II}$, the highest convection rate was recorded with OPM fuel of $7.392 \mathrm{~W} / \mathrm{m}^{2}$.

(2) At the combustion temperature for all points studied, OPM fuel shows a better trend than PKS and EFB fuels. The highest combustion temperature obtained from OPM fuel on M-I reached $884^{\circ} \mathrm{C}$. However, the temperature of the PKS combustion process was higher at $896^{\circ} \mathrm{C}$ but showed a poor trend.

(3) The convection heat rate of the highest EFB combustion process reached $6.268 \mathrm{~W} / \mathrm{m}^{2}$ recorded in $\mathrm{M}-\mathrm{I}$, while the EBF highest combustion temperature reached only $776^{\circ} \mathrm{C}$.

(4) Overall, the measurement results for M-IV showed the lowest compared to M-I, M-II, and M-III.

\section{Data Availability}

The data collected in this study have been incorporated into the article as a whole. The data contained in this article are experimental data (oil palm biomass burning). The data contained in this study are the result of basic research that has not been previously published.

\section{Conflicts of Interest}

All authors declare that they have no conflicts of interest.

\section{Acknowledgments}

This research was supported by the Kemenristek Dikti and Higher Education Syiah Kuala University, Research Institutions, and community service with the contract number 166/UN11/SPK/PNBP/2021.

\section{References}

[1] Y. Wang, L. Liu, and M. Yao, "Experimental and numerical study on the impact of low-temperature reforming products of BD60 on engine combustion and emission characteristics," Fuel, vol. 288, Article ID 119621, 2021.

[2] A. P. Singh, V. Kumar, and A. K. Agarwal, "Evaluation of comparative engine combustion, performance and emission characteristics of low temperature combustion (PCCI and RCCI) modes," Applied Energy, vol. 278, Article ID 115644, 2020.

[3] V. D. Chaudhari and D. Deshmukh, "Diesel and diesel-gasoline fuelled premixed low temperature combustion (LTC) engine mode for clean combustion," Fuel, vol. 266, Article ID 116982, 2020.

[4] G. Jia, L. Li, and D. M. Zhang, "Effect analysis on combustion and emission characteristics of a rotary burner fueled by biomass pellet fuel," Journal of Chemistry, vol. 2020, Article ID 3618382, 12 pages, 2020.

[5] G. Krishnamoorthy and C. Wolf, "Assessing the role of particles in radiative heat transfer during oxy-combustion of coal and biomass blends," Journal of Combustion, vol. 2015, Article ID 793683, 15 pages, 2015.

[6] Q. Ma, Q. Zhang, and Z. Zheng, "An experimental assessment on low temperature combustion using diesel/biodiesel/C2, C5 alcohol blends in a diesel engine," Fuel, vol. 288, Article ID 119832, 2021. 
[7] M. R. Erdiwansyah, R. Mamat, M. S. M. Sani, K. Sudhakar, A. Kadarohman, and R. E. Sardjono, "An overview of Higher alcohol and biodiesel as alternative fuels in engines," Energy Reports, vol. 5, pp. 467-479, 2019.

[8] B. Chen, D. B. Ilies, N. Hansen, H. Pitsch, and S. M. Sarathy, "Simultaneous production of ketohydroperoxides from low temperature oxidation of a gasoline primary reference fuel mixture," Fuel, vol. 288, Article ID 119737, 2021.

[9] B. Nie, X. He, R. Zhang, W. Chen, and J. Zhang, "The roles of foam ceramics in suppression of gas explosion overpressure and quenching of flame propagation," Journal of Hazardous Materials, vol. 192, no. 2, pp. 741-747, 2011.

[10] K. Jin, Q. Duan, J. Chen, K. M. Liew, L. Gong, and J. Sun, "Experimental study on the influence of multi-layer wire mesh on dynamics of premixed hydrogen-air flame propagation in a closed duct," International Journal of Hydrogen Energy, vol. 42, no. 21, pp. 14809-14820, 2017.

[11] L. Pang, C. Wang, M. Han, and Z. Xu, "A study on the characteristics of the deflagration of hydrogen-air mixture under the effect of a mesh aluminum alloy," Journal of Hazardous Materials, vol. 299, pp. 174-180, 2015.

[12] V. Ratna Kishore, M. R. Ravi, and A. Ray, "Effect of hydrogen content and dilution on laminar burning velocity and stability characteristics of producer gas-air mixtures," Journal of Combustion, vol. 2008, Article ID 310740, 8 pages, 2008.

[13] W. R. Chapman and R. V. Wheeler, "CCLXXXIII.-The propagation of flame in mixtures of methane and air. Part IV. The effect of restrictions in the path of the flame," Journal of the Chemical Society, vol. 129, pp. 2139-2147, 1926.

[14] Y. Wan, C. Wang, Q. Li, and X. Luo, "Experimental study of premixed hydrogen-air flame quenching in a channel with the perforated plate," Fuel, vol. 263, Article ID 116733, 2020.

[15] B. K. Maheshwari, R. Karwa, and S. K. Gharai, "Performance study of solar air heater having absorber plate with halfperforated baffles," ISRN Renew Energy, vol. 2011, Article ID 634025, 13 pages, 2011.

[16] C. J. Wang and J. X. Wen, “The effect of a perforated plate on the propagation of laminar hydrogen flames in a channel-a numerical study," International Journal of Hydrogen Energy, vol. 39, no. 36, pp. 21335-21342, 2014.

[17] Q. Li, X. Sun, X. Wang, Z. Zhang, S. Lu, and C. Wang, "Geometric influence of perforated plate on premixed hydrogen-air flame propagation," International Journal of Hydrogen Energy, vol. 43, no. 46, pp. 21572-21581, 2018.

[18] H. Wei, K. Li, J. Zhao, and L. Zhou, "Experimental investigation on the propagation of flow and flame in a confined combustion chamber equipped with a single-hole perforated plate," International Journal of Hydrogen Energy, vol. 45, no. 56, pp. 32589-32597, 2020.

[19] C. S. Cho, J. H. Sa, K. K. Lim et al., "Development of methane and nitrous oxide emission factors for the biomass fired circulating fluidized bed combustion power plant," The Scientific World Journal, vol. 2012, Article ID 989242, 9 pages, 2012.

[20] M. Erdiwansyah, R. Mahidin, R. Mamat, M. S. M. Sani, F. Khoerunnisa, and A. Kadarohman, "Target and demand for renewable energy across 10 ASEAN countries by 2040," The Electricity Journal, vol. 32, no. 10, Article ID 106670, 2019.

[21] M. R. Erdiwansyah, M. S. M. Sani, and K. Sudhakar, "Renewable energy in Southeast Asia: policies and recommendations," Science of The Total Environment, vol. 670, 2019.

[22] L. Jian, H. Bai, W. Zhao, and J. Liang, "Electrification and renewable energy generation," The Scientific World Journal, vol. 2015, Article ID 275238, 2 pages, 2015.
[23] E. Erdiwansyah, M. Mahidin, H. Husin et al., "Investigation of availability, demand, targets, and development of renewable energy in 2017-2050: a case study in Indonesia," International Journal of Coal Science \& Technology, vol. 8, pp. 1-17, 2021.

[24] M. I. Shahidul, M. L. Malcolm, S. Begum, M. S. J. Hashmi, M. S. Islam, and J. J. Eugene, "Renewable energy production from environmental hazardous palm oil mill waste materials: a review," in Encyclopedia of Renewable and Sustainable Materials, pp. 902-914, Elsevier, Oxford, UK, 2020.

[25] Q. Wu, T. C. Qiang, G. Zeng, H. Zhang, Y. Huang, and Y. Wang, "Sustainable and renewable energy from biomass wastes in palm oil industry: a case study in Malaysia," International Journal of Hydrogen Energy, vol. 42, no. 37, pp. 23871-23877, 2017.

[26] S. K. Loh, "The potential of the Malaysian oil palm biomass as a renewable energy source," Energy Conversion and Management, vol. 141, pp. 285-298, 2017.

[27] M. Erdiwansyah, H. Mahidin, H. Husin, M. Nasaruddin, M. Zaki, and Muhibbuddin, "A critical review of the integration of renewable energy sources with various technologies," Protection and Control of Modern Power Systems, vol. 6, no. 1 , p. 3, 2021.

[28] M. R. Hani, M. Mahidin, H. Husin et al., "Experimental studies on combustion characteristics of oil-palm biomass in fluidized-bed: a heat energy alternative," Journal of Advanced Research in Fluid Mechanics and Thermal Sciences, vol. 68, no. 2, pp. 9-28, 2020.

[29] S. Ge, S. Y. Foong, N. L. Ma et al., "Vacuum pyrolysis incorporating microwave heating and base mixture modification: an integrated approach to transform biowaste into ecofriendly bioenergy products," Renewable and Sustainable Energy Reviews, vol. 127, Article ID 109871, 2020.

[30] S. S. Lam, Y. F. Tsang, P. N. Y. Yek et al., "Co-processing of oil palm waste and waste oil via microwave co-torrefaction: a waste reduction approach for producing solid fuel product with improved properties," Process Safety and Environmental Protection, vol. 128, pp. 30-35, 2019.

[31] R. K. Liew, W. L. Nam, M. Y. Chong et al., "Oil palm waste: an abundant and promising feedstock for microwave pyrolysis conversion into good quality biochar with potential multiapplications," Process Safety and Environmental Protection, vol. 115, pp. 57-69, 2018.

[32] J. P. Holman, "Perpindahan Kalor (Terjemahan E. Jasfi). Jakarta Penerbit Erlangga," 1988.

[33] T. L. Bergman, F. P. Incropera, A. S. Lavine, and D. P. Dewitt, Introduction to Heat Transfer, John Wiley \& Sons, Hoboken, NJ, USA, 2011.

[34] M. Erdiwansyah, H. Husin, M. Nasaruddin et al., "Combustion efficiency in a fluidized-bed combustor with a modified perforated plate for air distribution," Process, vol. 9, 2021.

[35] X. Liu, Y. Wang, S. Li, and J. Wang, "Convection heat transfer of supercritical $\mathrm{CO} 2$ in a single fracture in enhanced geothermal systems," International Communications in Heat and Mass Transfer, vol. 123, Article ID 105170, 2021. 